\title{
A View from Young Oncologists on Clinical Trials in Turkey: Obstacles and Solution Proposals
}

\author{
Tulay AKMAN ${ }^{1}$, Ozgur TANRIVERDI ${ }^{2}$, Mehmet A. OZTURK ${ }^{3}$, Ibrahim PETEKKAYA ${ }^{4}$, \\ Hakan BAKKAL ${ }^{5}$, Ozlem U. SONMEZ ${ }^{6}$, Nilufer AVCI ${ }^{7}$, Seyda ZENGIN ${ }^{8}$, \\ Gorkem AKSU ${ }^{9}$, Gokhan OZYIGIT ${ }^{10}$, Huseyin ABALI ${ }^{11}$ \\ ${ }^{1}$ Tepecik Training and Research Hospital, Department of Medical Oncology, Izmir \\ ${ }^{2}$ Sitki Kocman University Faculty of Medicine, Department of Medical Oncology, Mugla \\ ${ }^{3}$ State Hospital, Department of Medical Oncology, Hatay-TURKEY. \\ ${ }^{4}$ Avukat Cengiz Gokcek Training and Research Hospital, Department of Medical Oncology, Gaziantep \\ ${ }^{5}$ Bulent Ecevit University Faculty of Medicine, Department of Radiation Oncology, Zonguldak \\ ${ }^{6}$ Yeditepe University Faculty of Medicine, Department of Medical Oncology, Istanbul \\ ${ }^{7}$ State Hospital, Department of Medical Oncology, Balikesir \\ ${ }^{8}$ Akdeniz University Faculty of Medicine, Department of Medical Oncology, Antalya \\ ${ }^{9}$ Kocaeli University Faculty of Medicine, Department of Radiation Oncology, Kocaeli \\ ${ }^{10}$ Hacettepe University Faculty of Medicine, Department of Radiation Oncology, Ankara \\ ${ }^{11}$ Baskent University Faculty of Medicine, Department of Medical Oncology, Adana-TURKEY
}

\begin{abstract}
There is a new improvement in oncology nearly in every day as a result of preclinical or clinical. As the number of publication per capita, Turkey is far behind the other developed European countries. For example, the number of publications in oncology field is 2.134 .964 in the world, it is 15.576 in our country. The most important obstacles for clinical trials in Turkey may be listed as financial problems, difficulties of working conditions, time limitation due to work intensity, inadequate experienced/trained man-power, absence of assistance team at all steps of a scientific trial, difficulties faced during project planning and ethics committee submissions, and lack of motivation. In this article, we, as young oncologists, aimed to discuss the place of Turkey in areas of scientific and clinical trials in the world; underlying causes for inadequate number, type and quality of national studies and possible solution proposals in our country.
\end{abstract}

Keywords: Oncology, Clinical trials, Turkey

ÖZET

Genç Onkologların Bakış Açısı ile Türkiye'deki Klinik Araştırmalar: Engeller ve Çözüm Önerileri

Günümüzde onkoloji alanında her geçen gün deneysel ve klinik araştırmaların sonucu olarak yeni bir gelişme olmaktadır. Kişi başına düşen yayın sayısına bakıldığında, Türkiye diğer gelişmiş Avrupa ülkelerinden epeyce geride yer almaktadır. Örneğin tüm dünyada kanser alanında yapılııs olan yayınların sayısı 2,134,964 iken, Türkiye'dekilerin sayısının toplamı 15.576'dır ve toplam yayın sayısı nüfus oranları ile karşılaştııılığında diğer gelişmiş Avrupa ülkelerine göre epeyce geride kalmaktadır. Türkiye'de klinik çalışmaların önündeki en önemli engellerin finansal sorunlar, çalışma şartlarının zorlukları, iş yoğunluğu nedeniyle zaman kısıtılı̆̆ı, deneyimli-eğitimli insan gücü eksikliği, bilimsel çalışmanın tüm aşamalarında yardımcı olacak bir ekibin eksikliği, proje hazırlama ve etik kurul izin sürecinde yaşanan sıkıntılar, motivasyon eksikliği olduğu düşünülebilir. Biz genç onkologlar olarak bu yazımızda; dünya genelinde ülkemizin bilimsel ve klinik araştırmalardaki yerini, bilimsel araştırmaların yapılamamasının nedenlerini, ülkemizde yapılmakta olan yayınların çeşit ve kalitesini, bizim ülkemize ait varolan gerçekleri ve bunlara yönelik getirilebilecek çözüm önerilerini tartışmayı amaçladık.

Anahtar kelimeler: Onkoloji, Klinik araştırmalar, Türkiye 


\section{INTRODUCTION}

In our era, not a single day passes without an new development in basic and clinical oncology every, secondary to increased momentum of production of new information.Thorough these researches that quality of our care for patients increases day by day, which translates into continuously increasing cure rates and survival figures for many types of cancer. In our globalization age where speed of communication is so fast, we have the chance to observe our country and the rest of the world and make comparisons. As a result we question our position in the world everday. We believe we have 2 options: To continue to consume the knowledge generated elsewhere, or to become an active player in the field. Inquiring ourselves with questions such as "Are there enough clinical trials conducted in our country?", "What is the quality of the clinical trials conducted?", "Why cannot we, oncologists, perform significant (practice changing) scientific researches?" and realizing our deficits led to the foundation of "Young Researchers Working Group (YRWG)". Our aim, as the YRWG, is to determine our current position and problems; to define what we can perform better under the existent conditions; and to improve our deficient aspects by continuing education in country or elsewhere.

We, as young Turkish oncologists, want to contribute more both in quality and quantity to scintific knowledge generated from our country. Turkish Oncology Group, founded in 1989 by leading oncologist in our country to promote multicenter and multidisciplinary nation-wide trials, hold yearly meetings to develop trials. At the latest one, we were given the opportunity to discuss the problems in researches in oncology as young oncologists by the organizing committee.

In the present article; we aimed to discuss the place of our country in the world; type and quality of national publications, realities of our country, underlying causes and possible solution proposals through the young oncologist's point of view.

\section{Current Condition of Clinical Trials in Turkey and Comparison with other Countries}

In 2011, Research and Development (R\&D) expenditure in the world was nearly 127 billion $\$$, whereas Turkey had an R\&D expenditure of 60 million \$, which was $0.05 \%$ of the total budget. $R \& D$ trials are divided into basic researches and clinical researches. Exploration of new molecules, identification of the area of use for new molecules, and re-evaluation of a drug make-up of the basic researches, and clinical tests are performed in the clinical research part. Together these two contribute to the process of drug development with long duration and high cost. ${ }^{1}$

Currently, it is accepted that $R \& D$ competence of a country is parallel with its clinical trial volume. In an assessment of year 2011, it was reported that United States of America (USA) and European community (EC) countries occupied the first line in number of clinical trials sponsored by the industry (Figure 1). In the same assessment, it was reported that Turkey was the 16th in pharmaceutical industry in the world, whereas it is at the 36th position when clinical trials were considered. ${ }^{1}$

Germany, France, United Kingdom, Spain, and Italy are the first five countries which value $\mathrm{R} \& \mathrm{D}$, and they are defined as EC5. These countries are accepted to have strong indicators in the pharmaceutical industry. USA and Japan are the other prominent countries after the EC5 countries. On the other hand, China, India, Russia, Brazil, and Turkey are considered among countries with recent development potentials, and these countries are defined as developing countries. ${ }^{1}$

Number of scientific studies performed all over the world up until January 2014 is 157.252 ; whereas it is 6.528 among the Middle Eastern countries and in our country it is 1373 in Turkey. When we compare it with our current population, it is observed that Turkey is far behind the world (Figure 2). ${ }^{1}$

When publications related to cancer were reviewed, it was found that $2.947(5.1 \%)$ out of 57.380 publications; 1.297 titles (2.2\%), and 1.345 (2.3\%) key words were originated from Turkey. A search performed by "Pubmed" as the basic search engine indicated that there were 2.134.964 articles published in cancer field in the world, whereas the number of articles from Turkey was (cancer[MeSH Major Topic]) AND turkey [Affiliation] 15.576. Similarly, according to year 2012 data, total of articles published was 1.258; and when the number was compared with population ratio, it was observed that Turkey was far behind the developed European countries such as Germany, France, and Italy. The number of publications per million people is 16.77 in Turkey; 69.59 in USA, 69.50 in Greece, 71.0 in Italy, 82.88 in France and Israel. In the year 2012, case reports formed the majority of publications from Turkey; and numbers of publications related to randomized clinical trials, 


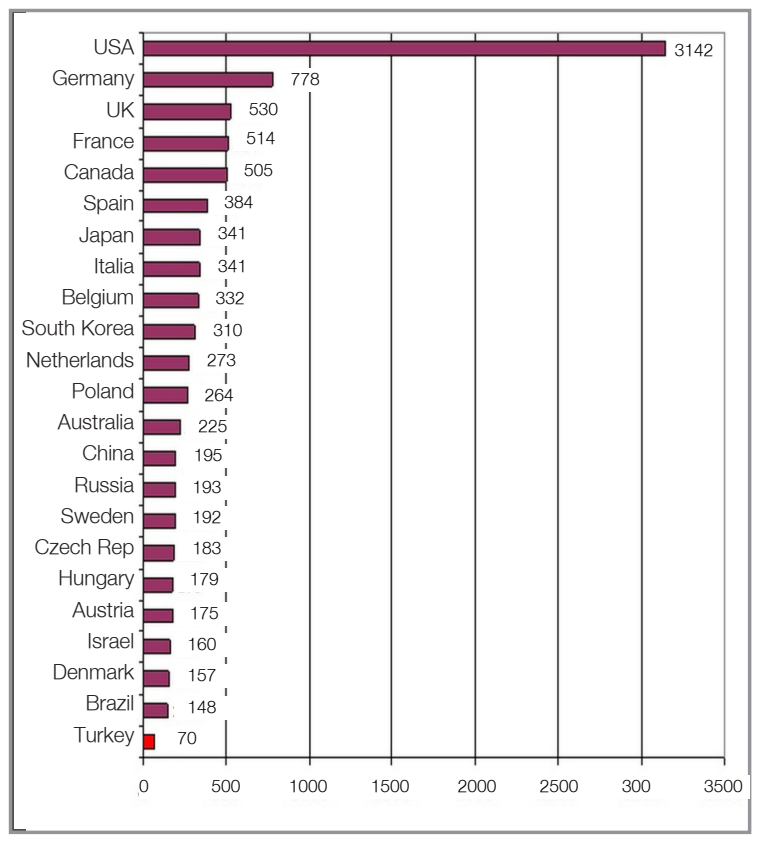

Figure 1. Numbers of sponsored clinical trials by the industry, 2011*(adapted from www.clinicaltrials.gov.tr) (Access date: 19/02/2014). clinical controlled trials, and especially phase studies were far behind the publications in the world (Table $1)^{2}$

\section{Difficulties in Conducting a Clinical Trial in Tur- key}

Conducting a clinical trial in Turkey generally has many diffculties. ${ }^{3}$ The way the current global healthcare system works, which has been founded on "capital and service", places routine occupational works in the center of our profession. And this affects equally physicians working at different health care systems: University hospital, Training and Research hospital and Governmental hospital. Some physicians are are both clinicians and scientist who are trying to conduct clinical research. For the most clinician-scientists in oncology, there is an extreme imbalance in favor of routine work. It is generally seen that research is something to be done in spare time or after the work hours.

Some of the problems may be listed as follows: Almost no time left from the daily routine; incomplete recording of patient data because of strenuous condi-



Figure 2. Regional distribution of all ongoing trials in the world, 2014* (adapted from www.clinicaltrials.gov.tr) (Access date: 19/02/2014). 


\begin{tabular}{|llll|}
\hline \multicolumn{3}{|l|}{ Table 1. Types and numbers of publications from Turkey, 2012* } & \\
\hline Type of Manuscripts & Turkey & Worldwide & \\
\hline Total & 14288 & 1154537 & 19.0 \\
Case report & 6594 & 219454 & 15.7 \\
Review & 1018 & 181878 & 7.9 \\
Comparative research & 1327 & 91576 & 1.91 \\
Randomized, controlled & 271 & 22064 & 0.4 \\
Controlled, clinical & 94 & 4811 & 2.2 \\
Multicentric & 119 & 25511 & \\
Phase I & 4 & 8046 & \\
Phase II & 51 & 14500 & \\
Phase III & 3 & 3730 & \\
Phase IV & 3 & 77 & \\
Systematic review & 70 & 622879 \\
Meta-analyses & 16 & 2535 & \\
Guideline & 4 & & \\
\hline
\end{tabular}

tions at work, lack of a team, which would help at all steps of a clinical trial (data collection, data analysis, patient follow up, screening of medical files etc.), too-long approval processes, suspension of many projects in some centers because of inadequate number of patients, financial difficulties, and lack of motivation. ${ }^{4,5,6}$

The most important obstacle to tackle with is the lack of effective scientific politics. Although there is the Ministry of Science, Industry, and Technology in our country, there is no effective science politics yet. Existent legal regulations may be another barrier against performing trials. For example, in an investigator initiated trial, investigator has to find the money for standard drugs which are re-imbursed in daily practice. In reality, no other organization than a pharmaceutical company tends to pay for the clinical trial expenditure. Pharmaceutical companies naturally tend to support trials which are in line their future perspectives.

Another problem is the shortage of experienced and trained man-power. Clinical trial methodology is not the natural part of training in oncology in our country. Although there are sufficient number of cases and infrastructure in oncology field, numbers of investigating physicians, and assisting personnel in clinical trials are not sufficient.

Another important problem is the lack of financial support in performing clinical trials. Although there are financial supports that can be received from "TU-
BITAK", Scientific Research Projects (SRPs) incorporated in universities, and from societies; selectivity and difficulty in reaching those supports as well as small sizes of budgets do not help to solve the problem. Usually, researchers try to reach required materials for clinical trials (kits, experimental animal etc.) by their own means.

Project writing and difficulties at ethics committee approvals also decrease the motivation to perform scientific researches. According to effective regulations about clinical trials, especially phase II and III trials can be initiated after tiring approval steps. These are the most important drawbacks for conduction of prospective interventional trial, which is being coordinated by a Turkish center. Although sponsor or financial source is found, approval of regulatory authority takes too long. Even clinical trial departments of large pharmaceutical companies can not pass through the approval process in a timely manner. It is not unusual that a trial recruits the total number of patients abroad until ethics committee approval is attained in our country. It sometimes seems to us as researchers that members of ethics committees try to find the hidden doctor Frankenstein in the clinical trial: "They mut have been doing something unethical and I have to find it." As ethics committees have started to function in 2000s in Turkey, clinical trials have become safer and better designed for both researcher and volunteer aspects. ${ }^{7}$ However, this favorable condition has not relieved financial problems in phase II/ III trials. 
One of the other important problems is difficult working conditions, and intensity of work. Weekly working hours of Turkish healthcare service personnel are longer than their European colleagues, which limits time to be spared for clinical trial conduction. Number of researchers and academic personnel per university are decreased by increasing number of medical schools. Many clinician researchers have to care for significant number of patients in a day in order to be paid enough in our current health care policy system. The other reason for being too-busy with the patients in the medical oncology is the insufficient number of medical oncologist in our country currently. It is just over 400 hundred including fellows in training. Under such circumstances, academic personnel are not able to spare enough time for clinical trials when they have responsibilities in student and researcher training programs, administrative duties, and healthcare services like examination and performing surgery.

When all drawbacks are considered together, it is obvious that a physician, who calls himself a researcher, will feel burned out because of his/her workload at the hospital, ethics committee procedures, provision of financial sources, missing data, differences in technical facilities between the affiliations, lack of pluralist participation and team-work, and lack of communication and dynamism in teamwork. These factors may cause motivation loss in scientists who would like to become researchers.

\section{Solution Proposals to Increase the Number of Clinical Trials in Turkey}

Time: One of the most important causes that prevent conduction of clinical trials in Turkey is that physicians' heavy workload of routine healthcare responsibilities and that they should spend all of their daily work-time on patient care. Physicians should allocate from their spare time to plan and conduct clinical trials. Knowledge and energy of physicians should not be only used to escalate routine day-work in hospitals. During or after subspecialty training programs, certain work-days should be spared for physicians to encourage conducting clinical trials with actual values within their weekly programs. If such a reorganization is performed, physicians will orientate to perform high quality scientific studies without sacrificing their personal lives. Thus, studies with high scientific quality will be published, and new contributions to the literature will be made.
Knowledge and Facilities: Production of knowledge is both an obligation to survive and to compete in life and, from a population perspective, a debt to contribute in modern civilization. It is obvious that civilization horizons like social, economic, and humanity levels of populations, which can produce and sustain production of knowledge, are brilliant.

Scientific studies in oncology can be classified as basic, translational and clinical studies. Clinical studies in oncology form the basis where oncologist can generate new information in diagnosis, treatment, and follow up. Unfortunately, there are quite a few scientific studies from Turkey, which may be called practice-changing. One of the reasons may be lack of expertise and facilities.

A clinical trial is a scientific process, which starts with a question asked to resolve an important health problem; in which solutions are searched according to some principles, tests for hypothesis is built and results are interpreted by humans, and from which finally a decision is extracted. Therefore, the most important factor in a clinical trial is human. Individuals with problems (patients), clinical scientists to ask important questions, statisticians to determine methods, ethics committees and regulatory authorities, clinicians testing hypotheses, assisting nurses during the testing period, clinical study coordinators, and financial resources to cover them all are required to conduct a clinical trial.

Currently, expectations of academic structure and regulatory authorities from clinicians with academic qualifications working at universities are patient-care centered. Actually, the origin of word "university" is "universitas magistrorum et scholarium" (community of masters and scholars), 8 and it indicates what the current expectations should focus. In our opinion, academic staff should be divided as research oriented patient-care oriented, and training-oriented, so that the efficiency can be increased by taking an action from a different point of view. What we propose to expect from research-oriented clinical scientists is that they develop hypotheses about existent clinical problems, and prepare suitable testing environments for them while they are continuing their daily practices in a specific field of oncology. We believe that these three groups of clinicians will have very important duties in planning and conducting clinical trials in collaboration, and it will be much easier to reach the common target. 
Clinicians should be perceived as team members to conduct a clinical trial, and future scientists. They should be trained in patient enrollment in the clinical trial, patient follow up, and in general and/or specific rules of clinical trials to manage protocol compliance of the study. International and national training opportunities should be created for clinicians interested in clinical trials, and they should be encouraged to attend them, and also certifications should be regularly performed. Among these clinicians, candidates for academic staff or ones with academic positions should be directed to one of the 3 main divisions according to their interests and desires.

Expecting their contributions in translational or clinical trials, young clinicians should be encouraged to attend doctoral program or laboratory projects abroad, and these young clinicians should be entitled to research teams.

Starting from senior assistant physicians, who are having their subspecialty training in medical oncology field, project contests including how a question for a clinical trial is asked and ending up model clinical projects with real-life outcomes may be organized.

Positions for clinical trial assistance (nurse, center coordinator, medical secretary, computer programmer etc.) other than the physician should be identified, and certificated training programs should be prepared for them.

Collaboration: When the working hours in Turkey are compared especially with the ones in European and North American countries, ours are quite long and numbers of patients contacted in a day are higher, which causes shortage of time for studies and also decreased body and mental performances, so it is quite difficult to conduct scientific researches. Moreover, as we all know, there are many steps starting from designing to publication in performing clinical trials. It is usually difficult for every researcher to manage all of these by him-/herself. During collaborative works, time and energy are saved by task divisions, and the saved portions are transferred to increase the performances. In collaborative studies, all details are shared by brain-storming. The topics are analyzed. Every team member has his/her target, level of capability, and attitude to work. In collaborative studies, tasks are divided, and all details are considered and evaluated. Participants work more eagerly because of his/her responsibilities to both him-/herself and the team members. He/she is motivated. When the study reaches its target, self-esteems of participants are increased. The same things are valid also for retrospective studies. Cases from a single center generally do not have very strong data, which may increase the interest on international platforms. However, multicenter trials are more powerful statistically, and are more significant. Additionally, real existence in international platforms require strength, which is only possible if our publication quality is increased, and if we work collaboratively.

Finance and Regulations: Many developed and developing countries have focused on pharmaceutical industry at least 10 years ago, and they stood out in the competition. They drew important investments, which would enable them to become importing countries. Turkey is behind especially BRIC countries (Brazil, Russia, India, and China) in drawing these investments. In Turkey, total clinical trial budget is 60 million \$, and $80 \%$ of it is sponsored by global pharmaceutical firms.1 However, in order to reach a competitive level with other countries in clinical trials, the infrastructure and regulatory (related laws and regulations) issues should be solved by the Turkish government.

To achieve this goal, clinical trials being conducted in Turkey should be announced, and also importance of clinical trials should be described. Additionally;

1. Research know-how and researcher's motivation (researchers receive at most $30 \%$ of the "investigator's payment". This ratio is $17 \%$ in training and research hospitals) should be improved in universities, training and research hospitals, and governmental hospital (research rooms, research nurses, financial systems),

2. Providing financial resources for $R \& D$,

3 . The government should provide a stable environment economically as well as by releasing competent regulations with the European Union to draw global investments,

4. Providing tax advantage for international investors for R\&D, and supporting investments of manufacture,

5. Establishing collaborations between universities and the industry, and providing participation of supporting affiliations in scientific meetings are important. ${ }^{1}$

Working with the Mentor: Training programs, in forms of seminars and courses, have been held in 
Turkey for clinical trials since 2003. They were consistent with the standards of European Union. Seminars have been organized about important topics in study protocols and clinical research methodology, and clinical study applications under the supervisions of mentors. ${ }^{6}$ One of the most important criteria in designing and organization of a study is the mentor, responsible investigator. Mentor can be defined as an advisor, consultant, or guide. In other countries, mentors design study conditions appropriately for the study, and they are paid for their services. They are encouraged for clinical trials elsewhere, but mentors work volunteering with an extra performance in Turkey. It is hard to define an academic person for this position in Turkey, because the position is completely volunteer-based without additional payment, and there is intense patient load for academic people every day.

The most crucial step to overcome the obstacle is to eliminate the volunteer-based approach, and to add the time into daily working hours for encouragement.

\section{CONCLUSION}

Contribution in science should be the common intention of all academic society. Increasing the number and quality of scientific researches is important. Despite all problems and obstacles, increasing the number of scientific researches performed individually or collaboratively will re-establish the supply-demand equilibrium. It may be expected that governmental authority follows an approach which may solve existent problems to compete with rapid improvements in dynamic scientific fields like oncology. For the fulfillment of this expectation, scientists and supporters of R\&D studies must apply a continuous pressure governmental authority to ease the difficulties of conducting a trial.

In conclusion, it is believed that scientists, supporters for R\&D, and governmental authorities should work collaboratively and consistently to increase the number and quality of studies in oncology in Turkey so that they can include international phase II/III studies. As a knowledge-consumer country, our ultimate goal must be "an active player in the field" not only in oncology but in every field in science.

\section{REFERENCES}

1. Turkey Pharmaceutical Sector Vision 2023 Report Strategy Document. http://www.aifd.org.tr/PDF/2023_Rapor/2023_ strat_en.pdf (Access date: 19/02/2014).

2. Sencan O. Evaluation of Clinical trials that are conducted and published in Turkey. 9th National Oncological Researches Work-shop, November 20-24, 2013. Antalya, Turkey.

3. Akan H. Clinical research in Turkey. Turk J Hematol 24: 1-3, 2007.

4. Ilbars H, Yazgan S, Dagistanli S. Drug trials in Turkey (Turkish). GCP Journal (IKU) 7: 3-9, 2004.

5. Kansu E, Akbas O, Hayran M, et al. Clinical scientific research potentials in Turkey. The Monitor 6: 51-54, 2006.

6. Aydin E. Regulations governing drug trials in Turkey. Med Law 22: 95-103, 2003.

7. http://www.etymonline.com/index.php?term=university (Access date: 19/02/2014).

\section{Correspondence}

Dr. Tulay AKMAN

Tepecik Egitim ve Arastirma Hastanesi

Tibbi Onkoloji Bolumu

Gaziler Caddesi, No: 468

Yenisehir, IZMIR / TURKEY

Tel: (+90.232) 4443560

Fax: (+90.232) 4330756

e-mail: tulaytuzel@gmail.com 